\title{
PENGUJIAN EMPIRIK ATAS EKSPOSUR EKONOMI YANG DIHADAPI OLEH PERUSAHAAN SEKTOR OTOMOTIF DI INDONESIA
}

\author{
Romikul Ghurub \\ Department of Management FEB UMM \\ E-mail: ro.mi.cool.ghurub7@gmail.com
}

\begin{abstract}
The purpose of the research is to know whether the automotive sector companies operating in Indonesia is facing economic exposure. This study uses the Distributed Lag regression to determine whether there is economic exposure that must be faced by the automotive subsector in Indonesian companies listed on the Indonesia Stock Exchange during the period 2008 to 2013 or not.The results of the analysis show that the effect of the company's external economic exposure in the show by the exchange rate against foreign currencies (U.S. dollar and Japanese yen) are not shown to significantly affect the price of shares in companies listed automotive sector The Indonesia Stock Exchange. The results of this analysis can occur due to factors that affect economic exposure not only fixated on the exchange rate against foreign currencies but also there are other factors that affect the economy, such as interest rates and inflation.The results of simultaneous test ( $F$ test ) and partial test ( $t$ test ) which found results that support each addition has no significant effect, the rupiah exchange rate against the U.S. Dollar and Japanese Yen also has a coefficient of determination with such a small proportion is $2.8 \%$ and $0.01 \%$. Small proportion of this which reinforce that the rupiah exchange rate against foreign currencies does not have an influence on company's stock price.
\end{abstract}

Keywords: Economic Exposure, Exchange Rate, Stock Price, Regression Distributed Lag

\section{PENDAHULUAN}

Nilai tukar valas yang merupakan suatu harga untuk mata uasng tertentu terhadap mata uang negeri lain, yang berfungsi sebagai alat perdagangan yang penting dalam hubungan ekonomi antar Negara (Ilham, 2007). Transaksi dengan menggunakan nilai tukar terjadi karena adanya pertemuan antara pembeli dan penjual yang melakukan transaksi internasional. Valas juga dapat digunakan sebagai ukuran bagi para pebisnis yang ingin mencari modal dari luar negeri, ataupun sebaliknya jika ada investor yang ingin menanamkan modal.

Tabel 1 menggambarkan bahwa pergerakan perubahan nilai tukar rupiah terhadap dolar AS berfluktuasi dari tahun 2008 sampai dengan tahun 2013, namun memiliki kecenderungan penguatan (apresiasi) nilai tukarPergerakan rupiah yang 
cenderung menguat di mulai dari tahun 2009 yang mengalami pelemahan (depresiasi), Pada tahun
2010 nilai tukar rupiah mengalami peningkatan yang sangat baik.

Tabel 1. Nilai Tukar Rupiah terhadap Dolar AS dan Yen

\begin{tabular}{ccr}
\hline \hline Tahun & Kurs (Rp/US \$) & Kurs(Rp/¥) \\
\hline 2008 & $10,191.72$ & 94.920 \\
2009 & $10,898.32$ & 111.830 \\
2010 & $9,158.60$ & 104.184 \\
2011 & $8,890.70$ & 110.701 \\
2012 & $9,495.93$ & 118.308 \\
2013 & $10,511.43$ & 107.711 \\
\hline *Sumber: BPS & \\
\hline
\end{tabular}

Penguatan terhadap dolar ini terus berlanjut hingga tahun berikutnya yang juga meningkat sebesar 3\%, namun pada tahun 2012 nilai tukar rupiah kembali mengalami depresiasi nilai tukar sebesar 7\%. Nilai Tukar Rupiah pada tahun 2013 kembali harus turun dan mengalami depresiasi nilai tukar atas dolar As. Tabel 1 menggambarkan tentang pergerakan perubahan nilai tukar rupiah terhadap Yen Jepang berfluktuasi dari tahun 2008 sampai dengan tahun 2013, di mulai dari tahun 2009 yang mengalami pelemahan (depresiasi), Tahun 2010 nilai tukar rupiah mengalami peningkatan sebesar 7\%. Nilai Tukar Rupiah pada tahun berikutnya mengalami pelemahan (depresiasi) sebesar $6 \%$, begitu pula pada tahun 2012 nilai tukar rupiah mengalami depresiasi nilai tukar sebesar $7 \%$. Fluktuasi nilai tukar kembali terjadi pada 2013, dimana mata uang rupiah meningkat sebesar 9\%.Tabel 2 manggambarkan bahwa tingkat permintaan atas kendaraan bermotor di Indonesia selalu meningkat di setiap tahunnya. Perbedaan yangsangatjauh atas jumlahpermintaan sepeda motor juga terlihat melalui Tabel 2 tersebut.

Dengan adanya fenomena inilah

Tabel 2. Perkembangan Jumlah Kendaraan Bermotor Menurut Jenis tahun 2005-2011

\begin{tabular}{cccccc}
\hline Tahun & Mobil Penumpang & Bis & Truk & Sepeda Motor & Jumlah \\
\hline 2005 & 5076230 & 1110255 & 2875116 & 28531831 & 37623432 \\
2006 & 6035291 & 1350047 & 3398956 & 32528758 & 43313052 \\
2007 & 6877229 & 1736087 & 4234236 & 41955128 & 54802680 \\
2008 & 7489852 & 2059187 & 4452343 & 47683681 & 61685063 \\
2009 & 7910407 & 2160973 & 4452343 & 52767093 & 67336644 \\
2010 & 8891041 & 2250109 & 4687789 & 61078188 & 76907127 \\
2011 & 9548866 & 2254406 & 4958738 & 68839341 & 85601351 \\
$2012 *$ & 9524666 & 1945288 & 4723315 & 77755658 & 93948927 \\
\hline
\end{tabular}

Sumber : Kantor Kepolisian Republik Indonesia

*Sumber: Kakorlantas Polri, Editor: Zulkifli BJ 
yang membuat penulis mencoba mengangkat topik yang berhubungan dengan perusahaan otomitif yang berkecimpung di dunia bisnis sub sektor otomotif yang telah go public. Fenomena ini yang memungkinkan untuk diamati pengaruh yang dialami oleh perusahaan kendaraan roda dua atas perubahan nilai tukar rupiah dari mata uang Dollar AS.Alasan fenomena tersebut yang menjadikan penulis tertarik mengangkat judul "Pengujian Emprik Atas Eksposur Ekonomi yang Dihadapi Perusahaan Sektor Otomotif Di Indonesia".

Pembatasan Masalah dalam penelitian ini perusahaan yang dipilih menjadi obyek penelitian berasal dari industri subsektor otomotif yang tercatat di Bursa Efek Imdonesia. Eksposur yang dibahas dalam penelitian ini tentang kurs mata uang Rupiah terhadap US Dolar dan Rupiah terhadap Yen Jepang. Data perusahaan sendiri dalam penelitian ini adalah data harga saham perusahaan. Dalam penelitian ini data yang digunakan merupakan data bulanan.Tujuan penelitian yang digunakan dalam penelitian ini adalahuntuk mengetahui apakah perusahaan sector otomotif yang beroperasi di Indonesia menghadapai eksposur ekonomi.

\section{TINJAUAN PUSTAKA}

$$
\text { Setiadi }
$$

menggunakannya pada harga saham perusahaan di sector barang konsumsi di Indonesia, dalam hal ini perusahaan rokok. Hasil penelitiannya menunjukkan bahwa secara simultan perubahan kurs, IHSG dan inflasi dari tahun 2002 hingga 2006 mempengaruhi eksposur
Indonesia. Perusahaan yang coba diamati oleh peneliti adalah perusahaan

ekonomi perusahaan industri rokok, sehingga diperoleh hasil yang menunjukkan bahwa eksposur ekonomi berpengaruh secara signifikan terhadap harga saham perusahaan industry rokok yang tercataan di BEI.

Eksposur sendiri dapat dibagi ke dalam 3 tipe, yaitu: Eksposur Ekonomi, Eksposur Transaksi, dan Eksposur Translasi. Eksposur Ekonomi adalah sejauh mana nilai perusahaan akan dipengaruhi oleh perubahan tak terduga dalam nilai tukar. (Eun dan Resnick, 2002).Eksposur transaksi dapat didefinisikan sebagai sensitivitas "menyadari" nilai mata uang domestik arus kas kontraktual perusahaan dalam mata uang asing untuk tak terduga perubahan kurs. Eksposur Translasi sendiri mengacu pada potensi laporan keuangan konsolidasi perusahaan yang dapat dipengaruhi oleh perubahan nilai tukar.

Faktor-faktor yang memperngaruhi eksposur ekonomi menurut Shaphiro (1999) antara lain sebagai berikut: a) Di mana perusahaan menjual produknya (dalam atau luar negeri). b) Kompetitior utama perusahaan baik di dalam mauppun diluar negeri. c) Kepekaan permintaan barang terhadap harga (elastis atau inelastis). d) Dimana perusahaan memproduksi produknya (di luar atau di dalam negeri). e) Input perusahaan berasal dari dalam atau dari luar negeri. f) Bagaimana penetapan harga input atau outputnya (ditetapkan 
berdasarkan harga pasar dunia atau pasar domestis). f) Inflasi dengan melihat prosentase IHK.

Menurut Eun dan Resnick (2002), eksposur terhadap risiko mata uang dapat di ukur secara tepat dengan dua cara, yaitu: 1) pengukuran sensitivitas laba rugi terhdap nilai-nilaimasa depanmata uang lokaldariaset perusahaan(dan kewajiban) dan; 2) arus kas operasiperusahaanterhadap

perubahanacakdalam nilai tukar.Sedangkan Aset terdiri dari asset berwujud seperti properti, pabrik dan peralatan, inventaris, yang kemudian disebut financial asset.

Untuk melakukan analisa terhadap factor-faktor yang diteliti dalam penelitian ini, maka diajukan hipotesis sebagai berikut: 1 . H0: $\beta=$ 0: a) Tidak terdapat pengaruh yang signifikan antara nilai tukar Rupiah atas Dollar AS terhadap harga saham perusahaan sektor otomotif yang terdaftar di BEI. b) Tidak terdapat pengaruh yang signifikan atas nilai tukar Rupiah Terhadap Yen Jepang terhadap harga saham perusahaan sektor otomotif yang terdaftar di BEI. 2. H1: $\beta \neq 0$ : a) Terdapat pengaruh yang signifikan antara nilai tukar Rupiah atas Dolar AS terhadap harga saham perusahaan sektor otomotif yang terdaftar di BEI. b) Terdapat pengaruh yang signifikan atas nilai tukar Rupiah Terhadap Yen Jepang terhadap harga saham perusahaan sektor otomotif yang terdaftar di BEI.

\section{METODE PENELITIAN}

Jenis penelitian yang digunakan adalah Deskriptif dengan pendekatan kuantitatif terhadap fenomena atau populasi tertentu. Definisi Operasional Variabel yang digunakan dalam penelitian ini antara lain: a) Kurs Spot: Penelitian ini memilih dolar AS dan Yen Jepang. Dolar AS digunakan karena merupakan mata uang asing yang paling sering digunakan pada hampir setiap transaksi yang dialkukan oleh semua Negara yang ada di dunia ini termasuk Indonesia.

Kemudian dipilihnya Yen Jepang karena jumlah perusahaan otomotif yang beroperasi di Indonesia berasal dari Jepang. b) Harga Saham Perusahaan: Harga saham perusahaan yang dimaksudkan dalam penelitian ini adalah harga saham perusahaan yang terdapat pada pasar sekunder, Harga saham ini adalah harga per lambar saham yang dikeluarkan oleh perusahaan.

Jenis Data yang digunakan dalam penelian ini menggunakan data sekunder. Data sekunder dalam penelitian ini berupa data laporan keuangan perusahaan yang menjadi obyek penelitian dari tahun 2008 sampai dengan 2013. Penelitian ini juga menggunakan data sekunder lain yang digunakan yaitu Kurs tukar Rupiah terhadap mata uang asing asing tahun 2008-2013. Sumber data yang digunakan dalam penelitian ini adalah harga saham perusahaan pada pasar sekunder pada Yahoo Finance. Serta data lain seperti Nilai Tukar Rupiah terhadap dolar AS dan Yen Jepang dari website Bank Indonesia www.bi.co.id.

Populasi dalam penelitian ini adalah Harga Saham perusahaan pada sektor otomotif yang tercata di BEI yang berjumlah 21 perusahaan. Penentuan sampel pada penelitian ini 
dilakukan dengan menggunakan purposive sampling. Kriteria sampel antara lain: a) Perusahaan sektor otomotif yang tercatat di Bursa Efek Indonesia (BEI) selama periode penelitian yaitu tahun 2008 - 2013 . b) Memiliki data selama periode penelitian untuk faktor - faktor yang diteliti yaitu harga saham perusahaan yang diperioleh melalui laporan keuangan perusahaan maupun publikasi dari yahoo finance selama periode 2008 - 2013.

Teknik pengumpulan data yang digunakan untuk menunjang pembahasan ini yaitu metode dokumentasi Anwar (2012).Teknik Analisis Data yang digunakan antara lain: Pertama adalah Analisis Regresi Leg yang didistribusikan. Untuk mengetahui pengaruh variabel independen terhadap variabel dependen, maka digunakan model Regresi Leg yang didistribusikan dengan persamaan sebagai berikut:

$\mathrm{Y}=\mathrm{a}+b \mathrm{x}_{\mathrm{t}}+b \mathrm{x}_{\mathrm{t}-1}+b \mathrm{x}_{\mathrm{t}-2}+b \mathrm{x}_{\mathrm{t}-3}+b \mathrm{x}_{\mathrm{t}-4}+b \mathrm{x}_{\mathrm{t}-5}$

Keterangan:

$\mathrm{Y}=$ Nilai

Perusahaan

(HargaSaham Perusahaan)

a $=$ Konstanta

$\mathrm{b} \quad=$ Koefisien Regresi

$\mathrm{Xt}=$ Kurs tukar rupiah terhadap dolar AS

Xt-1 = Kurs tukar rupiah terhadap dolar pada tahun sebelumnya

Et $=$ Error term, diasumsikan 0

Langkah kedua adalah menghitung Koefisien determinasi (Coefficient of Determination) dengan simbol $\mathrm{r}^{2}$ : yaitu nilai untuk mengukur besarnya kontribusi $\mathrm{X}$ terhadap variasi (naik turunnya) $\mathrm{Y}$. Variasi $Y$ lainnya (sisanya) disebabkan oleh faktor lain yang juga mempengaruhi $\mathrm{Y}$ dan sudah termasuk dalam kesalahan pengganggu (disturbance error) (Supranto, 2001: 205).

$\mathrm{r}^{2}=\left(\frac{\sum\left(X_{i}-\bar{X}\right)\left(Y_{i}-\bar{Y}\right)}{\sqrt[n]{\frac{1}{n} \sum\left(X_{i}-\bar{X}\right)} \sqrt{\frac{1}{n} \sum\left(Y_{i}-\bar{Y}\right)}}\right)^{2}$

Langkah

ketiga menggunakan Uji Hipotesis : a) Uji - F (uji koefisien secara serempak). Uji $F$ digunakan untuk mengetahui tingkat signifikan, variabel yang mempengaruhi (independen variabel) terhadap variable yang dipengaruhi (dependen variabel). b) Uji-t (pengujian secara individu). Uji-t dilakukan untuk mengetahui apakah secara individu antara variabel independent Eksposur ekonomi (nilai tukar mata uang rupiah 2008-2013) berpengaruh terhadap variable dependen nilai perusahaan (Harga Saham perusahaan).

\section{HASIL PENELITIAN DAN PEMBAHASAN}

Menghitung atau membuat lag (jeda waktu) pada data kurs tukar rupiah terhadap mata uang asing yang telah diperoleh. penetuan panjang lag optimal yang digunakan adalah metode Alt dan Timbergen (Prosedur Sekuensial), sehingga dari Periode pengamatan selama 6 tahun, sehingga maksimal dapat dibuat lag (jeda waktu) sebanyak 5 lag.

Selanjutnya juga didapatkan analisis regresi dengan variabel 1 lag yaitu $Y$ pada $X_{t}, X_{t-1}$,analisis regresi dengan variabel lag 2 yaitu $Y$ pada $\mathrm{X}_{\mathrm{t}}, \mathrm{X}_{\mathrm{t}-1}$, dan $\mathrm{X}_{\mathrm{t}-2}$, analisis regresi dengan variabel lag 3 yaitu $Y$ pada $\mathrm{X}_{\mathrm{t}}, \quad \mathrm{X}_{\mathrm{t}-1}, \quad \mathrm{X}_{\mathrm{t}-2}$ dan $\mathrm{X}_{\mathrm{t}-3}, \quad$ dan 
seterusnya hingga regresi lag yang terakhir.

$$
\text { Regresi Lag yang }
$$

didistribusikan (Distributed-Lag).

Perhitungan regresi yang dilakukan atas kurs tukar rupiah terhadap dolar AS adalah sebagai berikut: Pertama, Analisis Regresi Tanpa Variabel Lag. Rumus persamaan untuk analisis regresi tanpa variabel lag sebagai berikut: $\mathrm{Y}=20149.380$ $1.453 \mathrm{X}_{\mathrm{t}}$. Hasil perhitunngan yang telah dilakukan menunjukkan nilai $\mathrm{R}^{2}$ (Koefisien Determinasi) sebesar 0.019 atau $1.9 \%$. Makna ini diperkuat dengan adanya uji $\mathrm{t}$ (uji secara parsial pada tingkat signifikansi 0.000 pada alpha 0.05 . Hasil yang serupa ditunjukkan oleh uji f (uji secara simultan).

Kedua, Analisis Regresi Dengan Variabel Lag 1. Rumus persamaan untuk analisis regresi dengan variabel lag 1 sebagai berikut:Y $=17,538.028-1.359 \mathrm{Xt}+$ $0.208 \mathrm{X}_{\mathrm{t}-1}$. Hasil perhitunngan menunjukkan nilai $\mathrm{R}^{2}$ (Koefisien Determinasi) sebesar 0.023 atau 2.3\%. Makna ini diperkuat dengan adanya uji $t$ yang menunjukkan hasil 2 koefisien yang signifikan, yaitu pada tingkat signifikansi 0.000 dan 0.006 pada alpha 0.05 . Hasil yang serupa ditunjukkan oleh uji f (uji secara simultan).

Ketiga, Analisis Regresi Dengan Variabel Lag 2. Rumus persamaan untuk analisis regresi dengan variabel lag 2 sebagai berikut: $\mathrm{Y}=12,041.366-0.832 \mathrm{X}_{\mathrm{t}}+$ $0.049 \mathrm{X}_{\mathrm{t}-1}+0.242 \mathrm{X}_{\mathrm{t}-2}$. Hasil perhitunngan menunjukkan nilai $\mathrm{R}^{2}$ (Koefisien Determinasi) sebesar 0.028 atau $2.8 \%$. Makna ini diperkuat dengan adanya uji yang menunjukkan 2 koefisien yang signifikan pada tingkat signifikansi 0.016 dan 0.007 pada alpha 0.05. Hasil yang serupa ditunjukkan oleh uji f (uji secara simultan).

Keempat, Analisis Regresi dengan Variabel Lag 3. Rumus persamaan untuk analisis regresi dengan variabel lag 3 sebagai berikut: $\mathrm{Y}=12,682.095$

$0.904 \mathrm{X}_{\mathrm{t}}+0.068 \mathrm{X}_{\mathrm{t}-1}+0.171 \mathrm{X}_{\mathrm{t}-2}+0.0$ $75 \mathrm{X}_{\mathrm{t}-3}$. Hasil perhitunngan menunjukkan nilai $\mathrm{R}^{2}$ (Koefisien Determinasi) sebesar 0.028 atau $2.8 \%$. Makna ini diperkuat dengan adanya uji yang menunjukkan 1 koefisien yang signifikan pada tingkat signifikansi 0.001 pada alpha 0.05 . Hasil yang serupa ditunjukkan oleh uji f (uji secara simultan).

Kelima, Analisis Regresi Dengan Variabel Lag 4. Rumus persamaan untuk analisis regresi dengan variabel lag 4 sebagai berikut: $\mathrm{Y}=10,661.987-0.706 \mathrm{X}_{\mathrm{t}}+$ $0.070 \mathrm{X}_{\mathrm{t}-1}+\quad 0.180 \mathrm{X}_{\mathrm{t}-2}+$ $0.159 \mathrm{X}_{\mathrm{t}-3}-0.119 \mathrm{X}_{\mathrm{t}-4}$. Hasil perhitunngan menunjukkan nilai $\mathrm{R}^{2}$ (Koefisien Determinasi) sebesar 0.029 atau 2.9\%. Makna ini diperkuat dengan adanya uji yang menunjukkan tidak ada 1 koefisienpun yang signifikan pada alpha 0.05. Hasil yang berbeda ditunjukkan oleh uji $f$ (uji secara simultan) yang signifikan dengan tingkat signifikansi 0.000 pada alpha 0.05 .

Keenam, Analisis Regresi Dengan Variabel Lag 5. Rumus persamaan untuk analisis regresi dengan variabel lag 4 sebagai berikut: $Y=9,318.760-0.575 \quad X_{t}+$ $0.063 \quad \mathrm{X}_{\mathrm{t}-1}+0.205 \quad \mathrm{X}_{\mathrm{t}-2}+$ $0.147 \mathrm{X}_{\mathrm{t}-3}-0.080 \mathrm{X}_{\mathrm{t}-4}-$ $0.083 \mathrm{X}_{\mathrm{t}-5}$. Hasil perhitunngan menunjukkan nilai $\mathrm{R}^{2}$ (koefisien 
Determinasi) sebesar 0.028 atau 2.8\%. Makna ini diperkuat dengan adanya uji yang menunjukkan tidak ada 1 koefisienpun yang signifikan alpha 0.05. Hasil yang berbeda ditunjukkan oleh uji f (uji secara simultan) yang signifikan dengan tingkat signifikansi 0.000 pada alpha 0.05 .

Perhitungan regresi yang dilakukan atas kurs tukar rupiah terhadap Yen Jepang adalah sebagai berikut: Pertama, Analisis Regresi Tanpa Variabel Lag. Rumus persamaan untuk analisis regresi dengan variabel lag sebagai berikut: $\mathrm{Y}=1815.928+37.415 \mathrm{X}_{\mathrm{t}}$. Hasil perhitunngan menunjukkan nilai $\mathrm{R}^{2}$ (koefisien Determinasi) sebesar 0.001 atau $0.1 \%$. Makna ini diperkuat dengan adanya uji yang menunjukkan tidak ada 1 koefisienpun yang signifikan alpha 0.05 . Hasil yang berbeda ditunjukkan oleh uji f (uji secara simultan) yang signifikan dengan tingkat signifikansi 0.000 pada alpha 0.05 .

Kedua, Analisis Regresi Dengan Variabel Lag 1. Rumus persamaan untuk analisis regresi dengan variabel lag sebagai berikut: $\mathrm{Y}=5529.368-21.454 \mathrm{Xt}+$ $29.262 \mathrm{X}_{\mathrm{t}-1}$. Hasil perhitunngan menunjukkan nilai $\mathrm{R}^{2}$ (Koefisien Determinasi) sebesar 0.010 atau $1.0 \%$. Makna ini diperkuat dengan adanya uji yang menunjukkan terdapat 1 koefisien yang memilikinilai signifikan, yaitu 0.000 pada alpha 0.05 . Hasil yang serupa ditunjukkan oleh uji f (uji secara simultan).

Ketiga, Analisis Regresi Dengan Variabel Lag 2. Rumus persamaan untuk analisis regresi dengan variabel lag 2 sebagai berikut: $\mathrm{Y}=\mathrm{Y}=5130.485-14.910 \mathrm{X}_{\mathrm{t}}$ $+1.138 \mathrm{X}_{\mathrm{t}-1}+31.238 \mathrm{X}_{\mathrm{t}-2}$. Hasil perhitunngan menunjukkan nilai $\mathrm{R}^{2}$ (Koefisien Determinasi) sebesar 0.020 atau 2.0\%. Makna ini diperkuat dengan adanya uji yang menunjukkan hanya 1 koefisien yang signifikan pada tingkat signifikansi 0.000 pada alpha 0.05 . Hasil yang serupa ditunjukkan oleh uji f (uji secara simultan).

Keempat, Analisis Regresi dengan Variabel Lag 3. Rumus persamaan untuk analisis regresi dengan variabel lag 3 sebagai berikut:Y=4932.090 - $12.831 \mathrm{X}_{\mathrm{t}}+$ $0.722 \mathrm{X}_{\mathrm{t}-1}+32.560 \quad \mathrm{X}_{\mathrm{t}-2^{-}} 1.571$ $\mathrm{X}_{\mathrm{t}-3}$. Hasil perhitunngan menunjukkan nilai $\mathrm{R}^{2}$ (Koefisien Determinasi) sebesar 0.020 atau $2.0 \%$. Makna ini diperkuat dengan adanya uji yang menunjukkan hanya 1 koefisien yang signifikan pada tingkat signifikansi 0.003 pada alpha 0.05 . Hasil yang serupa ditunjukkan oleh uji f (uji secara simultan).

Kelima, Analisis Regresi Dengan Variabel Lag 4. Rumus persamaan untuk analisis regresi dengan variabel lag 4 sebagai berikut:Y=5910.823 - 25.120 $\mathrm{X}_{\mathrm{t}}+$ $7.334 \quad \mathrm{X}_{\mathrm{t}-1}+26.328 \quad \mathrm{X}_{\mathrm{t}-2}+$ $19.529 \mathrm{X}_{\mathrm{t}-3^{-}} \quad 26.122 \quad \mathrm{X}_{\mathrm{t}-4}$. Hasil perhitunngan menunjukkan nilai $\mathrm{R}^{2}$ (Koefisien Determinasi) sebesar 0.026 atau 2.6\%. Makna ini diperkuat dengan adanya uji yang menunjukkan hanya 2 koefisien yang signifikan pada tingkat signifikansi 0.017 dan 0.002 pada alpha 0.05 . Hasil yang serupa ditunjukkan oleh uji f (uji secara simultan).

Keenam, Analisis Regresi Dengan Variabel Lag 5. Rumus persamaan untuk analisis regresi dengan variabel lag 4 sebagai 
berikut:Y=7599.829 - $43.270 \mathrm{X}_{\mathrm{t}}+$ $10.215 \quad \mathrm{X}_{\mathrm{t}-1}+26.543 \quad \mathrm{X}_{\mathrm{t}-2}+$ $17.968 \mathrm{X}_{\mathrm{t}-3^{-}}-13.881 \quad \mathrm{X}_{\mathrm{t}-4^{-}}-21.822$ $\mathrm{X}_{\mathrm{t}-5}$. Hasil perhitunngan menunjukkan nilai $\mathrm{R}^{2}$ (Koefisien Determinasi) sebesar 0.028 atau $2.8 \%$. Makna ini diperkuat dengan adanya uji yang menunjukkan hanya 2 koefisien yang signifikan pada tingkat signifikansi 0.016 dan 0.054 pada alpha 0.05 . Hasil yang serupa ditunjukkan oleh uji f (uji secara simultan).

Menentuan Panjang Lag Optimal. Yaitu dengan menentukan Persamaan Regresi Dengan Panjang Lag Optimal Untuk Kurs Rupiah Terhadap Dollar AS. Persamaan regresi yang memiliki panjang lag paling optimal adalah regresi dengan variabel lag 5 karena pada seluruh persamaan regresi tidak mengalami perubahan tanda dari positif menjadi negatif ataupun sebaliknya, yaitu $\mathrm{Y}=$ $9,318.760-0.575 \mathrm{X}_{\mathrm{t}}+0.063 \mathrm{X}_{\mathrm{t}-1}+$ $0.205 \mathrm{X}_{\mathrm{t}-2}+0.147 \mathrm{X}_{\mathrm{t}-3}-0.080 \mathrm{X}_{\mathrm{t}-4}$ $-0.083 X_{t-5}$ dapat diinterpretasikan sebagai berikut:Nilai koefisen $X_{t}\left(\beta_{1}\right)$ bernilai negatif (-) yang menandakan hubungan tidak searah, artinya apabila Economic Exposure meningkat, maka harga saham akan mengalami penurunan atau sebaliknya.

Nilai koefisen $X_{t-1}\left(\beta_{2}\right)$ bernilai positif $(+)$ yang menandakan anatara variabel $\mathrm{X}$ dan $\mathrm{Y}$ memiliki hubungan searah, artinya apabila Eksposur Ekonomi pada periode t-1 $\left(\mathrm{X}_{\mathrm{t}-1}\right)$ meningkat maka harga saham akan mengalami peningkatan juga atau sebaliknya jika mengalami penurunan.

Nilai koefisen $X_{t-2}\left(\beta_{2}\right)$ bernilai positif (+) yang menandakan anatara variabel $\mathrm{X}$ dan $\mathrm{Y}$ memiliki hubungan searah, artinya apabila Eksposur Ekonomi pada periode t-2 $\left(X_{t-2}\right)$ meningkat maka harga saham akan mengalami peningkatan juga atau sebaliknya jika mengalami penurunan.

Nilai koefisen $X_{t-3} \quad\left(\beta_{3}\right)$ bernilai positif $(+)$ yang menandakan anatara variabel $\mathrm{X}$ dan $\mathrm{Y}$ memiliki hubungan searah, artinya apabila Eksposur Ekonomi pada periode t-3 $\left(\mathrm{X}_{\mathrm{t}-3}\right)$ meningkat maka harga saham akan mengalami peningkatan juga atau sebaliknya.

Nilai koefisen $\mathrm{X}_{\mathrm{t}-4} \quad\left(\beta_{4}\right)$ bernilai negatif (-) yang menandakan anatara variabel $\mathrm{X}$ dan $\mathrm{Y}$ memiliki hubungan yang tidak searah, artinya apabila Eksposur Ekonomi meningkat maka harga saham akan mengalami penurunan atau sebaliknya.Nilai koefisen $X_{t-5}\left(\beta_{5}\right)$ bernilai negatif (-) yang menandakan anatara variabel $\mathrm{X}$ dan $\mathrm{Y}$ memiliki hubungan yang tidak searah, artinya apabila Eksposur Ekonomi meningkat maka harga saham akan mengalami penurunan atau sebaliknya.

Menentukan Persamaan Regresi Dengan Panjang Lag Optimal Untuk Kurs Rupiah Terhadap Yen Jepang dengan cara Persamaan regresi yang memiliki panjang lag paling optimal adalah regresi tanpa variabel lag, karena pada persamaan regresi kedua (regresi dengan variabel lag 1 koefisien regresi dari $\mathrm{X}_{\mathrm{t}-1}\left(\beta_{1}\right)$ mengalami perubahan dari positif menjadi negative, yaitu $\mathrm{Y}=1815.928$ $+37.415 \mathrm{Xt}$ dapat diinterpretasikan sebagai berikut:Nilai koefisen $X_{t}\left(\beta_{1}\right)$ bernilai negatif (-) yang menandakan hubungan tidak searah, artinya 
apabila Economic Exposure meningkat, maka harga saham akan mengalami penurunan atau sebaliknya.

$$
\text { Koefisien Determinasi }
$$

dihitung Untuk Kurs Tukar Rupiah Terhadap Dolar AS.Berdasarkan hasil perhitungan diperoleh nilai adjusted $\mathrm{R}$ square sebesar 0.028 . Hal ini berarti dapat diartikan sebagai setiap perubahan yang terjadi pada harga saham perushaan dipengaruhi oleh perubahan eksposur ekonomi (nilai tukar rupiah terhadap Dolapr AS) sebesar $2.8 \%$ (selebihnya diakibatkan oleh variabel lain yang tidak dibahas dalam penelitian ini).

Koefisien

Determinasi

dihitung Untuk Kurs Tukar Rupiah Terhadap Yen Jepang. Berdasarkan hasil perhitungan diperoleh nilai adjusted $\mathrm{R}$ square sebesar 0.001 $(0,1)$. Hasil perhitungan ini berarti dapat diartikan sebagai setiap perubahan yang terjadi pada harga saham perushaan dipengaruhi oleh perubahan eksposur ekonomi sebesar $0,1 \%$ (selebihnya dipengaruhi oleh variabel lain yang tidak dibahas dalam penelitian ini).

Selanjutnya Menghitung Uji signifikansi (Uji Parsial (Uji t)): Uji Parsial (Uji t) pertama, Untuk Kurs Tukar Rupiah Terhadap Dolar AS. Berdasarkan pada persamaan regresi: $Y=9,318.760-0.575 \quad X_{t}+0.063$ $\mathrm{X}_{\mathrm{t}-1}+0.205 \mathrm{X}_{\mathrm{t}-2}+0.147 \mathrm{X}_{\mathrm{t}-3}-$ $0.080 \mathrm{X}_{\mathrm{t}-4}-0.083 \mathrm{X}_{\mathrm{t}-5}$, . Diketahui bahwa $t_{\text {hitung }}$ untuk periode $t$ sebesar -1.388 , periode $\mathrm{t}-1$ sebesar 0.644 , periode $\mathrm{t}-2$ sebesar 1.722 , periode $\mathrm{t}-3$ sebesar 1.531 , periode $\mathrm{t}-4$ sebesar -0.832 , periode $\mathrm{t}-5$ sebesar 0.775 , sedangkan untuk $t_{\text {tabel }}$ sebesar \pm 1.962 .
Hasil tersebut menunjukkan bahwa dari hasil $t_{\text {hitung berada }}$ dalam area $\mathrm{H}_{0}$ diterima, artinya Eksposur Ekonomi pada periode ke $\mathrm{t}$ tidak berpengaruh secara signifikan terhadap harga saham. Uji Parsial (Uji t) kedua, Untuk Kurs Tukar Rupiah Terhadap Yen Jepang. Pada persamaan regresi $\mathrm{Y}=1815.928+$ 37.415 Xt Diketahui bahwa $t_{\text {hitung }}$ untuk periode $\mathrm{t}$ sebesar 1,430, sedangkan untuk $t_{\text {tabel }}$ sebesar \pm 1.962. Hasil tersebut menunjukkan

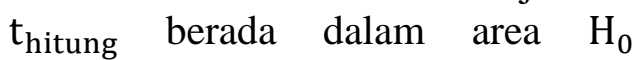
diterima, artinya Eksposur Ekonomi pada periode ke $t$ tidak berpengaruh secara signifikan terhadap harga saham.

Selanjutnya Menghitung Uji signifikansi (Uji Simultan (Uji f)). Yaitu Uji Simultan (Uji f) pertama, Untuk Kurs Tukar Rupiah Terhadap Dolar AS. Berdasarkan pada persamaan regresi:

$Y=9,318.760-0.575 X_{t}+0.063$

$\mathrm{X}_{\mathrm{t}-1}+0.205 \mathrm{X}_{\mathrm{t}-2}+0.147 \mathrm{X}_{\mathrm{t}-3}-$ $0.080 \mathrm{X}_{\mathrm{t}-4}-0.083 \mathrm{X}_{\mathrm{t}-5}$. Diketahui nilai $F_{\text {hitung }}(7,511)>F_{\text {tabel }}(2,105)$. Disimpulkan bahwa $\mathrm{H}_{0}$ ditolak yang artinya bahwa variabel bebas (eksposur ekonomi) secara simultan berpengaruh signifikan terhadap variabel terikat (harga saham).

Uji Simultan (Uji f) kedua, Untuk Kurs Tukar Rupiah Terhadap Yen Jepang. Berdasarkan pada persamaan regresi $\mathrm{Y}=1815.928+$ $37.415 \mathrm{Xt}$ diketahui nilai $\mathrm{F}_{\text {hitung }}(2.046) \quad<\mathrm{F}_{\text {tabel }} \quad$ (3.848). Disimpulkan bahwa $\mathrm{H}_{0}$ diterima yang artinya bahwa variabel bebas (eksposur ekonomi) secara simultan tidak berpengaruh signifikan terhadap variabel terikat (harga saham). 
Hasil analisis data yang telah dilakukan, dapat diketahui bahwa kurs tukar rupiah atas dolar AS terhadap harga saham yang menunjukkan bahwa selama 6 tahun penelitian kurs tukar rupiah memberikan pengaruh atas setiap perubahan harga saham dengan sifat yang selalu berfluktuatuif, kurs tukar rupiah selalu mengalami peningkatan pada tahun 2008 hinnga 2012 namun mengalami penuruan kontribusi pada tahun 2013.Hasil penelitian ini juga menemukan bahwa kurs tukar Rupiah atas Yen Jepang terhadap harga saham perusahaan juga memiliki hasil yang senada dengan kurs tukar Rupiah atas Dolar AS.

Berdasarkan pada analisis data ditemukan bahwa dalam penelitian ini pengaruh eksternal perusahaan yakni tentang eksposur ekonomi yang di tunjukkan oleh nilaiukar rupiah terhadap mata uang asing terbukti tidak berpengaruh secara signifikan terhadap harga saham. Faktor-faktor

yang mempengaruhi eksposur ekonomi bukan hanya terpaku pada kurs tukar rupiah terhadap mata uang asing, namun juga terdapat aktorfaktor perekonomian lain, seperti tingkat bunga dan inflasi.

\section{SIMPULAN}

Berdasarkan analisis data dan pembahasan yang telah dilakukan maka diperoleh kesimpulan bahwa perusahaan-perusahaan otomotif yang beroperasi di Indonesia tidak menghadapi Eksposur Ekonomi. Kesimpulan ini dapat diambil setelahmenemukan bahwa kurs tukar Rupiah terhadap Dolar AS dan Yen Jepang sebagai indikator pengukuran eksposur ekonomi, tidak memiliki pengaruh yang signifikan terhadap harga saham perusahaan.

Berdasarkan pada hasil penelitian ditemukan bahwa selain tidak memiliki pengaruh yang signifikan, kurs tukar Rupiah terhadap Dolar AS dan Yen Jepang juga memiliki nilai koefisien determinasi dengan proporsi yang begitu kecil yaitu $2.8 \%$ dan $0.01 \%$.

\section{DAFTAR PUSTAKA}

Agung Kurniawan. Selasa, 26 Februari 2013, 09:55 WIB. http://otomotif.kompas.com/

News/jumlah

kendaraanbermotor

2012.htm. Diunduh tanggal 23-12-2013, 08.33.

Dhona Listria Wulandari. 2013. Analisis Variabel-variabel Fundamental yang Berpengaruh terhadap Eksposur Ekonomi Perusahaan Industri Komoditas Pertambangan Terdaftar di BEI periode 2006-2010. Jurnal Universitas Brawijaya.

Eun,Cheol\&Resnick, Bruce.2001. "International Financial Management. Singapore:McGraw-Hill.

Faisal,M. 2001. "Manajemen Keuangan Internasional". Jakarta: Salemba Empat.

Ilham, M Setyadi. 2007.Analisis pengaruh eksposure konomi dan factor-faktor yang mempengaruhinya pada perusahaan sector barang konsumsi yang go public di Bursa Efek Jakarta.Skripsi UIN Jakarta. 
Levi, Maurice D. 2001. "Keuangan Internasional Buku 2". Yogyakarta: Erlangga.

Madura, Jeff. 2000. "Manajemen Keuangan Internasional, Edisi Empat Jilid 1". Jakarta: Erlangga.

Madura, Jeff.2006.”Manajemen Keuangan Internasional, buku 1, edisi8". Jakarta:Salemba Empat.

Risty.2013. http://morrycupcuppida.blogspot.com/

Sanusi, Anwar.2011."Metodologi Penelitian Bisnis". Jakarta: Salemba Empat.
Shapiro, Alan C.1999.Multinational Financial Management $6^{\text {th }}$-ed. John Wiley \& Sons, Inc.New York.

Supranto,J.2001."Statistika:

Teoridan Aplikasi, Edisi

ketujuh".Jakarta: Erlangga.Jatim

Prov. Feb 22, 2013.

http://bpm.jatimprov.go.id/Jumlah

KendaraanBermotor_BPM -

ProvinsiJawa Timur.htm. Di

unduhtanggal24-10-2013, 11:36 